\title{
OBITUARY.
}

\section{Sir William Boyd Dawkins.}

William Boyd Dawkins was born at Buttington, Welshpool, on 26th December, 1837 ; therefore at the time of his death he was in his 92nd year. He was educated at Rossall, and at Jesus College, Oxford, where he took a second class in classics and a first class in natural science and was the first holder of the Burdett-Coutts scholarship. He joined the Geological Survey in 1861, where he remained till 1869. In 1870 he became lecturer in geology at Owen's College, Manchester, and Professor in 1872, having been elected a Fellow of the Royal Society in 1867. At one time of his life he travelled a great deal and delivered the Lowell lectures at Boston in 1880. In 1882 he was elected an honorary Fellow of his college, and received the honour of knighthood in 1919.

His attention was early directed to the borderland between geology and history, in connection with which his early classical training stood him in good stead. He made a special study of the mammalia of late geological times, and was naturally attracted by the problems connected with Early Man. As much evidence was then being obtained from caves he began a careful exploration of some of them, studying their physical characteristics as well as their organic contents. While doing this work he was often led into positions of difficulty and even danger, for he was an intrepid explorer. The evidence obtained from the caves was summarized in his well known work, Cave Hunting, published in 1874. Another work, Early Man in Britain, appeared in 1880: in this the whole question of Prehistoric Man was reviewed, and his own contributions to it summarized.

About this time Dawkins appears to have been confronted with the question as to whether he should devote himself chiefly to pure or to applied geology. He chose the latter and his geological confrères have deplored the decision. It is possible, however, that his choice was a wise one, for his versatility was such that he might have. rebelled against too specialized a calling. As it is, he did much of value in various ways: his work for the city of Manchester was specially noteworthy, but these activities do not affect the geologist and need not be recorded here. As regards economic work his name is chiefly associated with the Channel Tunnel and the Kent Coalfield, but he did an enormous amount of work in connection with geological problems of all kinds, and never entirely abandoned pure geology. Late in life he returned once more to his early love, Pleistocene and Prehistoric animals, and was actually engaged within a few months of his death in studying the Prehistoric Mammalia of the East Anglian Fenland.

He had a sunny nature and a delightful personality, and had endeared himself to a large circle of acquaintances in all ranks of life. 